\title{
АДМІНІСТРАТИВНО-ПРАВОВІ ЗАСОБИ ДІЯЛЬНОСТІ РЕГІОНАЛЬНОГО ДЕПАРТАМЕНТУ СОЦІАЛЬНОГО ЗАХИСТУ НАСЕЛЕННЯ
}

Постановка проблеми. Соціальний захист населення - одна з головних функцій держави, яка здійснюється завжди і за будь-яких умов на користь непрацездатних, осіб з інвалідністю, пенсіонерів, малозабезпечених, оскільки здебільшого представники саме цього прошарку населення потребують підтримки. Виконання завдання соціального захисту населення покладено на Департамент соціального захисту населення. Пріоритетними напрямками його діяльності є: надання матеріальної та фінансової підтримки особам з інвалідністю, ветеранам війни та праці, самотнім громадянам, малозабезпеченим родинам із дітьми, постраждалим унаслідок Чорнобильської катастрофи та іншим незахищеним верствам району, здійснення контролю за своєчасною виплатою підприємствами та установами різних форм власності та господарювання заробітної плати, в тому числі дотримання вимог законодавства у сфері соціально-трудових відносин, оплати праці і належних умов праці, зайнятості.

Необхідність з'ясування адміністративно-правових засобів діяльності регіонального Департаменту соціального захисту населення, пов'язана із проведенням належної нормотворчої і правовиховної роботи задля створенням відповідних соціально-економічних умов у державі, створення достатнього рівня нормативно-правового регулювання суспільних відносин, і визначила актуальність даної статті.

Стан дослідження. Різні аспекти соціального захисту населення висвітлювалися в роботах багатьох вчених. Зокрема, дана тема висвітлена у працях вчених-економістів Л.І. Васечко [1], М.І. Мальованого [2], А.Л. Клименко [3] та інших. Метою цієї роботи є вираження власного бачення на адміністративно-правові засоби діяльності регіонального Департаменту соціального захисту населення.

Виходячи із цього, новизна статті полягає в авторському погляді на проблему з'ясування адміністративно-правових засобів діяльності регіонального Департаменту соціального захисту населення задля подальшого використання у практичній діяльності Департаменту соціального захисту населення Харківської обласної державної адміністрації.

Виклад основного матеріалу. Адміністративно-правові засоби діяльності регіонального Департаменту соціального захисту населення входять у сукупність адміністративно-правових засад його діяльності. Щоб визначити такі адміністративно-правові засади діяльності регіонального Департаменту соціального захисту населення, доцільно розкрити зміст ознак таких засад. Слово «засада» визначається у тлумачному словнику української мови в таких значеннях: 1. Основа чогось; те головне, на чому грунтується, базується що-небудь; 2. Вихідне, головне положення, принцип; основа світогляду, правило поведінки; 3. Спосіб, метод здійснення чого-небудь [4]. Термін «засади» вживається в Конституції України та назвах 
окремих законів України («Про засади державної регіональної політики», «Про Основні засади грошово-кредитної політики на 2016-2020 роки» та ін.), але вичерпне тлумачення його в жодному акті не подається.

У науці виокремлюються обов'язкові і факультативні елементи організаційно-правових засад, закріплених у законодавчих актах. Обов'язковими є: правова основа (законодавство); об'єкт правового регулювання; пріоритетні напрями; принципи; суб'єкти та їхні завдання, функції й повноваження; засоби (заходи, методи), за допомогою яких здійснюється урегулювання суспільних відносин, у тому числі й відповідальності; механізми контролю і нагляду. Факультативними називають: організацію співробітництва у відповідній сфері (галузі); інформаційне забезпечення; специфіку фінансування; особливості взаємодії та координації в певній сфері (галузі) [5].

3-поміж думок науковців також слід виділити думку, що адміністративно-правові засади складаються із трьох основних державно-управлінських елементів, а саме: моделі, функцій та форм. Модель визначає особливості соціального захисту населення на всіх владно-управлінських рівнях, функції закріплюють основні напрями (види) такої діяльності регіонального Департаменту соціального захисту населення, а форми характеризують зовнішній прояв конкретних організаційно-управлінських дій, спрямованих на безпосередню реалізацію зазначених функцій [6]. Також існує підхід, за якого адміністративно-правові засади діяльності характеризуються сукупністю адміністративно-правових норм, що визначають основні цінності, принципи, завдання, форми та методи нормотворчої і розпорядчої діяльності органів виконавчої влади [7].

Виходячи з того, що змістом адміністративно-правових засобів діяльності регіонального Департамент соціального захисту населення є його правовий статус, який закріплений законодавством України, вважаємо доцільним зосередитися саме на ньому. А саме на сукупності закріплених у нормах адміністративного права характеристик діяльності регіонального Департаменту соціального захисту населення, що врегульовані за допомогою адміністративно-правових засобів.

Сукупність адміністративно-правових засобів охоплюється адміністративно-правовим методом регулювання і передбачає застосовування регіональними департаментами соціального захисту населення в процесі правозастосовної діяльності для забезпечення регулювального впливу норм адміністративного права на управлінські суспільні відносини.

Серед регулятивних засобів виділяють:

- приписи - вказівки щодо обов'язкового вчинення певних дій;

- заборони - покладення юридичного обов'язку утримуватися від вчинення певних дій;

- дозволи - надання можливості вчинити певні дії або ж утриматися від їх вчинення на власний розсуд. Для адміністративно-правового регулювання як основний засіб регулювання використовується припис.

Термін «засіб» означає прийом, спосіб, спеціальну дію, що дає можливість здійснити що-небудь, досягти чого-небудь; знаряддя, предмет, сукупність пристроїв для здійснення певної діяльності [8, с. 326]. Загальним для всіх тлумачень засо- 
бу є те, що всі вони називають предмети та явища з позиції їх функціонального призначення та можливості використання для вирішення певних завдань.

3-поміж думок науковців щодо категорії «правові засоби», від якої існує похідне поняття «адміністративно-правові засоби», наведемо окремі. Так, під засобом розуміють з’єднуючу середню ланку між суб’єктом та об’єктом діяння, між ідеальною моделлю мислення й матеріальним результатом. Тому правові засоби є специфічним посередником, що включають як фрагменти ідеального (інструменти, засоби-встановлення: суб'єктивні права, обов'язки, пільги, заборони, заохочення, покарання тощо), так і фрагменти реального (технологію, засоби-діяння, спрямовані на використання інструментів, насамперед акти реалізації прав та обов'язків) [9, с. 360]. За іншим підходом правові засоби охоплюються правовим регулювання і утворюють цілісний, системний юридичний механізм, який забезпечує врегулювання всієї сукупності суспільних відносин, що є предметом правового регулювання [10, с. 245].

Питання правових засобів заслуговує на виокремлення в окрему категорію з огляду на їх функціональне призначення і роль як інструментів у вирішенні завдань, у нашому випадку - в діяльності регіонального Департаменту соціального захисту населення.

У науці під правовими засобами також розуміються закріплені конституцією, нормами законів або інших правових актів прийоми, способи впливу на суспільні відносини з метою досягнення певного результату. До таких відносять юридичні норми, правовідносини, індивідуальні правовстановлюючі веління й приписи, акти правозастосовних органів тощо. Відмічається також існування засобів-діянь, за допомогою яких можна досягти поставлених цілей. Наявність прописаних у нормативно-правових актах засобів діяльності автоматично не приводить до потрібного ефекту. Потрібні також дії, зусилля, активність, пов'язані з використанням наданих у законодавстві інструментів. Засоби-встановлення та засоби-діяння створюють разом необхідний і самодостатній для досягнення конкретної цілі інформаційно-енергетичний комплекс ресурсів [11, с. 363]. Так, засоби охоплюють правовий інструментарій і його використання під час отримання бажаного результату.

До переліку правових засобів входять адміністративно-правові, кримінально-правові, цивільно-правові, дисциплінарні та інші. Адміністративно-правові засоби є досить різноманітними. Зміст адміністративно-правових засобів розкривається науковцями по-різному. В.К. Колпаков до засобів, які містять у собі адміністративно-правовий метод регулювання, відносить приписи, заборони, дозволи. Приписи - це покладання прямого юридичного зобов'язання чинити ті чи інші дії в умовах, що передбачені правовою нормою. Заборони - це покладання прямих юридичних обов'язків не чинити тих чи інших дій в умовах, передбачених правовою нормою. Дозволи - це юридичний дозвіл чинити в умовах, передбачених нормою, ті чи інші дії або утримуватись від їх вчинення за власним бажанням [12, с. 56-57].

Адміністративно-правові засоби діяльності регіонального Департаменту соціального захисту населення є методами практичного здійснення його цілей, завдань і функцій. Такими методами є систематизована сукупність кроків, які потрібно здійснити, щоб виконати задачі, що ставляться перед регіональним Департамен- 
том соціального захисту населення. Це певний алгоритм у діяльності Департаменту. До таких засобів відносять:

- нормативне встановлення чітких правил діяльності регіонального Департаменту соціального захисту населення;

- встановлення зобов'язань регіонального Департаменту соціального захисту населення та обов'язків уповноважених осіб Департаменту;

- встановлення повноважень уповноважених осіб регіонального Департаменту соціального захисту населення;

- встановлення юридичної відповідальності регіонального Департаменту соціального захисту населення;

- статистичне спостереження за діяльністю регіонального Департаменту соціального захисту населення;

- порядок застосуванням документального методу в діяльності регіонального Департаменту соціального захисту населення;

- порядок здійснення контролю в діяльності регіонального Департаменту соціального захисту населення;

- забезпечення обігу інформації в діяльності регіонального Департаменту соціального захисту населення;

- застосування математичного методу в діяльності регіонального Департаменту соціального захисту населення.

Адміністративно-правові засоби діяльності регіонального Департаменту соціального захисту населення $є$ втіленням правових норм і відображаються в конкретних положеннях, що сприяють досягненню певного завдання (цілі) [13, с. 149-154].

Відповідно до Типового положення про структурний підрозділ місцевої державної адміністрації, затвердженого постановою Кабінету Міністрів України від 26 вересня 2012 року № 887, структурний підрозділ в установленому законодавством порядку та в межах повноважень взаємодіє з іншими структурними підрозділами, апаратом місцевої держадміністрації, органами місцевого самоврядування, територіальними органами міністерств, інших центральних органів виконавчої влади, а також підприємствами, установами та організаціями з метою створення умов для провадження послідовної та узгодженої діяльності щодо строків, періодичності одержання і передачі інформації, необхідної для належного виконання покладених на нього завдань та здійснення запланованих заходів [14]. Тобто у своїй діяльності регіональний Департамент соціального захисту населення серед кроків, які потрібно здійснити, щоб виконати задачі, що ставляться перед ним, може взаємодіяти з низкою інших суб’єктів.

Таким чином, адміністративно-правовими засобами діяльності регіонального Департаменту соціального захисту населення є систематизована сукупність кроків. Тобто такі засоби визначаються адміністративно-процесуальними нормами і містять послідовності дій, що визначають порядок діяльності Департаменту та порядок здійснення окремих адміністративних процедур. Такі алгоритми дій $є$ досить об'ємними для відображення і містяться в низці нормативно-правових актів. Комплексно висвітлити їх у рамках нашого дослідження неможливо, відтак зосередимося на окремих із них. 
Зокрема, діяльність Департаменту соціального захисту населення Харківської обласної державної адміністрації включає численні процедури та процесуальні аспекти досягнення цілей Департаменту, виконання його завдань і функцій. Наведемо лише окремі з них.

Звернення громадян є одним із засобів захисту їхніх прав та законних інтересів. Організація роботи з розгляду звернень та особистого прийому громадян є одним із важливих напрямків діяльності регіонального Департаменту соціального захисту населення, спрямованих на захист конституційних прав і свобод людини і громадянина, зміцнення законності та правопорядку.

Іншим прикладом застосування адміністративно-правових засобів $є$ процесуальні аспекти досягнення цілей Департаменту в діяльності колегії Департаменту соціального захисту населення Харківської обласної державної адміністрації, яка є постійним консультативно-дорадчим органом і утворюється для підготовки рекомендацій щодо виконання Департаментом соціального захисту населення Харківської обласної державної адміністрації своїх завдань, погодженого розгляду та вирішення питань, що належать до його компетенції, та для колективного і вільного обговорення найважливіших напрямів його діяльності. Організація роботи Колегії визначається положенням, а організаційною формою роботи Колегії є засідання. Порядок проведення засідання Колегії визначається окремим розділом положення про колегію, зокрема Департаменту соціального захисту населення Харківської обласної державної адміністрації. Такий порядок майже повністю складається з алгоритму дій, що визначають порядок проведення засідання Колегії, зокрема, передбачено обов'язкову реєстрацію членів Колегії, які беруть участь у засіданні; порядок роботи під час проведення спільних засідань колегій Департаменту та інших органів виконавчої влади; визначено, що засідання Колегії оформляються протоколами, які складаються відділом організаційно-аналітичної роботи управління організаційно-документального забезпечення Департаменту та підписуються головуючим на засіданні, візуються начальником управління організаційнодокументального забезпечення та працівником, який веде протокол; визначено, що рішення Колегії вводяться в дію наказами директора Департаменту та ін. [15].

Як приклад можна навести засідання колегії Департаменту соціального захисту населення Харківської обласної державної адміністрації від 27 травня 2019 року. На засіданні колегії Департаменту соціального захисту населення Харківської обласної державної адміністрації розглядалося питання «Про прийняття на державне утримання до інтернатних установ системи соціального захисту населення області громадян похилого віку та осіб з інвалідністю, які мають дітей або інших родичів працездатного віку» [16].

Діяльність Департаменту соціального захисту населення Харківської обласної державної адміністрації та підпорядкованих установ системи соціального захисту спрямована на виконання пріоритетних завдань державної соціальної політики. В останні роки це було проведення реформування системи житлових субсидій, пільг, соціальних допомог, підвищення якості та рівня доступності соціальних послуг, сприяння ініціативності територіальних громад у розв’язанні найгостріших соціальних проблем. 
Для досягнення поставлених цілей використовуються адміністративно-правові засоби: нормативне встановлення чітких правил діяльності Департаменту соціального захисту населення Харківської обласної державної адміністрації; встановлення обов'язків уповноважених осіб Департаменту; встановлення повноважень уповноважених осіб Департаменту; встановлення юридичної відповідальності уповноважених осіб Департаменту; здійснення аналізу роботи за відповідними напрямкам та статистичного спостереження за діяльністю Департаменту; визначення порядку документообігу в діяльності Департаменту; визначення порядку здійснення контролю в діяльності Департаменту; постійний моніторинг показників діяльності Департаменту та забезпечення обігу інформації в діяльності Департаменту.

Наприклад, Департамент соціального захисту населення Харківської обласної державної адміністрації здійснює інформування рай(міськ)управлінь соціального захисту населення, підвідомчих установ та закладів. Управління праці та управлінню фінансового забезпечення здійснює постійний контроль за використанням виділених із державного бюджету коштів. Також Департамент координує діяльність об’єднаних територіальних громад у частині організації та надання соціальних послуг, зокрема вразливим сім'ям з дітьми, громадянам похилого віку, особам з інвалідністю, бездомним особам та особам, звільненим із місць позбавлення волі [17].

Ще одним прикладом адміністративно-правових засобів у діяльності Департаменту соціального захисту населення Харківської обласної державної адміністрації є забезпечення обігу інформації, зокрема, через проведення семінар-нарад. Так, 5 вересня 2019 року Департаментом соціального захисту населення Харківської обласної державної адміністрації проведено семінар-нараду з керівниками структурних підрозділів місцевих органів соціального захисту населення районних державних адміністрацій, міст обласного значення з розгляду актуальних питань реалізації соціальної політики [18].

Засідання створених консультативних рад є одним із адміністративно-правових засобів діяльності Департаменту соціального захисту населення Харківської обласної державної адміністрації. Зокрема, 21 серпня 2019 року відбулось розширене засідання регіональної консультативної ради з реалізації в Харківській області у 2018-2020 роках пілотного проекту «Створення системи надання послуг раннього втручання» за участю представників місцевих органів виконавчої влади, об'єднаних територіальних громад, закладів охорони здоров'я. На засіданні регіональної консультативної ради обговорені актуальні питання щодо впровадження на місцях послуги раннього втручання [19].

Іншим прикладом проведення наради як адміністративно-правового засобу діяльності Департаменту є проведення 1 серпня 2019 року Департаментом соціального захисту населення обласної державної адміністрації наради із заступниками голів райдержадміністрацій, міст обласного значення, об’єднаних територіальних громадах, керівниками органів соціального захисту населення, представниками структурних підрозділів Харківської міської ради та обласної державної адміністрації. На нараді обговорені питання використання у 2019 році субвенції з державного бюджету місцевим бюджетам на проектні, будівельно-ремонтні роботи, придбання житла та приміщень для розвитку сімейних та інших форм виховання, 
наближених до сімейних, забезпечення житлом дітей-сиріт, дітей, позбавлених батьківського піклування, осіб з їх числа [20].

Створення і діяльність робочих груп з окремих питань соціального захисту населення в регіоні є наступним прикладом адміністративно-правового засобу діяльності Департаменту. Наприклад, 30 липня 2019 року відбулося засідання Робочої групи з питань гуманітарної допомоги, на якому розглядалося питання визнання гуманітарною допомогою лікарського препарату онкотерапевтичної дії. За результатами голосування членів Робочої групи було прийнято рішення рекомендувати голові обласної державної адміністрації визнати вантаж гуманітарною допомогою [21].

Робота регіональних комісій, що діють при Харківській обласній державній адміністрації, є ще одним прикладом застосування адміністративно-правового засобу діяльності Департаменту. Зокрема, у I та II кварталах 2019 року проведено 5 засідань Регіональної комісії з визначення даних про заробітну плату працівників за роботу в зоні відчуження в 1986-1990 роках, що діє при Харківській обласній державній адміністрації, на яких розглянуто 9 особових справ осіб, які постраждали внаслідок Чорнобильської катастрофи [22].

Через те, що Департамент соціального захисту населення Харківської обласної державної адміністрації виконує досить різноманітну діяльність, уніфікувати адміністративно-правові засоби діяльності регіонального Департаменту соціального захисту населення досить тяжко. Виходячи з напрямків діяльності Департаменту, можна виділити окремі напрямки застосування адміністративно-правових засобів діяльності Департаменту:

- особистий прийом у Департаменті соціального захисту населення Харківської обласної державної адміністрації;

- проведення засідань колегії Департаменту соціального захисту населення Харківської обласної державної адміністрації;

- порядок здійснення діяльності Департаменту у сфері соціально-трудових відносин, охорони праці та зайнятості населення (діяльність територіальної тристоронньої соціально-економічної ради, професійна орієнтація, реалізація програми зайнятості населення харківської області);

- порядок здійснення діяльності Департаменту у сфері державної соціальної допомоги;

- порядок здійснення діяльності Департаменту у сфері житлових субсидій;

-порядокздійсненнядіяльностіДепартаментуусферіпільгововогозабезпечення;

- порядок здійснення діяльності Департаменту у сфері соціальних послуг;

- порядок здійснення діяльності Департаменту у сфері соціального захисту осіб з інвалідністю;

- порядок здійснення діяльності Департаменту у сфері соціальної підтримки внутрішньо переміщених осіб;

- порядок здійснення діяльності Департаменту у сфері соціальної підтримки учасників АТО та ООС;

- порядок здійснення діяльності Департаменту у сфері соціального захисту громадян, які постраждали внаслідок чорнобильської катастрофи; 
- порядок здійснення діяльності Департаменту задля забезпечення гендерної рівності;

- взаємодія зінститутами громадянського суспільства соціального спрямування;

- діяльність спрямована на протидію торгівлі людьми;

- діяльність спрямована на запобігання та протидію домашньому насильству;

- діяльність спрямована на соціальний захист в об’єднаній територіальній громаді;

- реалізація оздоровлення та відпочинку дітей у ДП «УДЦ «Молода гвардія» та ДПУ «МДЦ «АРТЕК;

- організація надання гуманітарної допомоги;

- виконання програм використання фінансових ресурсів місцевого бюджету.

Висновки. Підсумовуючи викладене, під адміністративно-правовими засобами діяльності регіонального Департаменту соціального захисту населення необхідно розуміти сукупність адміністративно-правових норм, які розглядаються з позиції їх функціонального призначення для вирішення конкретних завдань регіонального Департаменту соціального захисту населення та регулювання відносин, що складаються в діяльності регіонального Департаменту соціального захисту населення.

\section{Jimepamypa}

1. Васечко Л.І. Фінансовий механізм соціального страхування в Україні : автореф. дис. ... канд. екон. наук : спец. 08.00.08 «Гроші, фінанси і кредит». Ірпінь. 2010. 23 с.

2. Мальований М.І. Фінансові аспекти функціонування системи соціального захисту населення в Україні : монографія. Умань : СПД Сочінський, 2016. 496 с.

3. Клименко А.Л. Соціальний захист і соціальне забезпечення в умовах євроінтеграції України: окремі аспекти. Теорія і практика правознавства. 2017. Вип. 2(12). С. 1-10.

4. Засада. Словник украйнської мови. Академічний тлумачний словник (1970-1980) в 11 томах. Tom 3, 1972. C. 300. URL: http://sum.in.ua/s/zasada.

5. Заброда Д.Г. Адміністративно-правові засади: сутність та зміст категорії. Адміністративне право і процес. Науково-практичний журнал, заснований Київським національним університетом імені Tараса Шевченка. 2013. № 2(4). URL : http://applaw.knu.ua/index.php/arkhiv-nomeriv/2-4-2013/ item/180-administratyvno-pravovi-zasady-sutnist-ta-zmist-katehoriyi-zabroda-d-h.

6. Логвиненко Б.О. Адміністративно-правові засади медичного забезпечення органів внутрішніх справ України : дис. ... канд. юрид. наук : 12.00.07. Дніпропетровськ, 2008. 20 с.

7. Панова Н.С. Адміністративно-правові засади розвитку державного управління в сучасній Україні : автореф. дис. ... канд. юрид. наук : спец. 12.00.07. Одеса, 2008. 19 с.

8. Великий тлумачний словник сучасної української мови / уклад. і гол. ред. В.Т. Бусел. Київ; Ірпінь : ВТФ «Перун», 2003. 1440 с.

9. Проблемы теории государства и права : учеб. пособие / под ред. М.Н. Марченко. Москва : Юристъ, 2002.620 с.

10. Хропанюк В.Н. Теория государства и права : учебник для вузов / Н.В. Хропанюк. Москва : лТД, 1996. $588 \mathrm{c.}$

11. Проблемы теории государства и права : учеб. пособие / под ред. М.Н. Марченко. Москва : Юристъ, 2002.620 с.

12. Колпаков В.К. Адміністративне право України : підручник / В.К. Колпаков. Київ : Юрінком Інтер, $1999.736 \mathrm{c.}$

13. Негодченко В. зміст адміністративно-правових способів і засобів забезпечення обігу інформації підрозділами інформаційно-аналітичного забезпечення та оперативного реагування органів національної поліції України. Підприємництво, господарство і право. 2017. № 3. С. 149-154.

14. Про затвердження Типового положення про структурний підрозділ місцевої державної адміністрації : Постанова Кабінет Міністрів України від 26.09.2012 № 887. База даних «Законодавство 
України»; Верховна Рада України. URL : https://zakon.rada.gov.ua/laws/show/887-2012-п (дата звернення: 25.08.2019).

15. Положення про колегію Департаменту соціального захисту населення Харківської обласної державної адміністрації : Розпорядження голови обласної державної адміністрації 19.02.2013 № 52 . Офіційний веб-сайт Харківська обласна державна адміністрація. URL : https://kharkivoda.gov.ua/ oblasna-derzhavna-administratsiya/struktura-administratsiyi/strukturni-pidrozdili/139/415/615 (дата звернення: 16.09.2019).

16. Засідання колегії Департаменту соціального захисту населення Харківської обласної державної адміністрації від 27 травня 2019 року. Офіційний веб-сайт Харківська обласна державна адміністрація. URL : https://kharkivoda.gov.ua/oblasna-derzhavna-administratsiya/struktura-administratsiyi/ strukturni-pidrozdili/139/140/98934 (дата звернення: 27.05.2019).

17. Про підсумки роботи Департаменту соціального захисту населення Харківської обласної державної адміністрації та підпорядкованих установ системи соціального захисту населення області за 2017 рік і пріоритетні напрямки роботи на 2018 рік : Рішення засідання колегії Департаменту соціального захисту населення Харківської обласної державної адміністрації від 08.02.2018 Офіційний веб-сайт Харківська обласна державна адміністрація. URL : https://kharkivoda.gov.ua/content/ documents/7/618/files/Rishennya_(kolegiya_08_02_2018).doc (дата звернення: 16.09.2019).

18. Семінар-нарада з розгляду актуальних питань реалізації соціальної політики щодо внутрішньо переміщених осіб. Офіційний веб-сайт Харківська обласна державна адміністрація. URL : https://kharkivoda.gov.ua/content/documents/1002/100149/Attaches/na_sayt.pdf (дата звернення: 16.09.2019).

19. Розширене засідання регіональної консультативної ради з реалізації в Харківській області у 2018-2020 роках пілотного проекту «Створення системи надання послуг раннього втручання» від 21.08.2019. Офіційний веб-сайт Харківська обласна державна адміністрація. URL: https://kharkivoda. gov.ua/content/documents/1000/99964/Attaches/dodatok_3_.pdf (дата звернення: 16.09.2019).

20. Інформація щодо проведення наради стосовно використання у 2019 році субвенції з державного бюджету місцевим бюджетам. Офіційний веб-сайт Харківська обласна державна адміністрація. URL : https://kharkivoda.gov.ua/content/documents/998/99751/Attaches/pres_reliz_narada_na_sayt_ oda_.pdf (дата звернення: 16.09.2019).

21. Засідання робочої групи з питань гуманітарної допомоги 30.07.2019. Офіційний вебсайт Харківська обласна державна адміністрація. URL : https://kharkivoda.gov.ua/content/ documents/998/99750/Attaches/zasidannya_robochoyi_grupi.pdf (дата звернення: 16.09.2019).

22. Про результати роботи Регіональної комісії з визначення даних про заробітну плату працівників за роботу в зоні відчуження в 1986-1990 роках у першому півріччі 2019 року / Офіційний веб-сайт Харківська обласна державна адміністрація. URL : https://kharkivoda.gov.ua/content/ documents/995/99472/Attaches/2.pdf (дата звернення: 16.09.2019).

\section{Анотація}

Шиарага Ю. І. Адміністративно-правові засоби діяльності регіонального департаменту соціального захисту населення. - Стаття.

Показаний власний погляд на адміністративно-правові засоби діяльності регіонального Департаменту соціального захисту населення. Визначено, що під адміністративно-правовими засобами діяльності регіонального Департаменту соціального захисту населення необхідно розуміти сукупність адміністративно-правових норм, які розглядаються з позиції їх функціонального призначення для вирішення конкретних завдань регіонального Департаменту соціального захисту населення та регулювання відносин, що складаються в діяльності регіонального Департаменту соціального захисту населення. Звернення громадян $€$ одним із засобів захисту їхніх прав та законних інтересів. Організація роботи з розгляду звернень та особистого прийому громадян є одним із важливих напрямків діяльності регіонального Департаменту соціального захисту населення, спрямованих на захист конституційних прав і свобод людини і громадянина, зміцнення законності та правопорядку. Наголошено, що сукупність адміністративно-правових засобів охоплюється адміністративно-правовим методом регулювання і передбачає застосовування регіональними департаментами соціального захисту населення в процесі правозастосовної діяльності для забезпечення регулювального впливу норм адміністративного права на управлінські суспільні відносини. Висвітлено зміст адміністративно-правових засобів діяльності регіонального Департамент соціального захисту населення. Надано види адміністративно-правові засоби діяльності регіонального Департаменту соціального захисту населення. Охарактеризовано окремі адміністративно-правові засоби діяльності Департаменту соціального захисту населення Харківської 
обласної державної адміністрації. 3'ясовано, що адміністративно-правові засоби діяльності регіонального Департаменту соціального захисту населення є методами практичного здійснення його цілей, завдань і функцій. Такими методами є систематизована сукупність кроків, які потрібно здійснити, щоб виконати задачі, що ставляться перед регіональним Департаментом соціального захисту населення.

Ключові слова: соціальний захист населення, адміністративно-правові засоби, соціальна допомога, Департамент соціального захисту населення.

\section{Summary}

Shparaha Yu. I. Administrative-legal means of the activities of the regional department of social protection of the population. - Article.

The own vision on administrative and legal means of activity of regional Department of social protection of the population is shown. It is determined that under the administrative remedies of the activity of the regional Department of social protection of the population it is necessary to understand the set of administrative and legal norms, which are considered from the point of their functional purpose for solving the specific tasks of the regional Department of social protection of the population and regulating the relations forming in the activity of the regional Department of social protection population. The appeal of citizens is one of the means of protecting their rights and legitimate interests. Organization of work on consideration of applications and personal reception of citizens is one of the important directions of activity of the regional Department of social protection of the population, aimed at protection of constitutional rights and freedoms of human and citizen, strengthening of law and order. It was emphasized that the set of administrative remedies is covered by the administrative-legal method of regulation and provides for the application by the regional departments of social protection of the population in the process of enforcement activities to ensure the regulatory influence of the rules of administrative law on managerial public relations. The content of administrative and legal means of activity of regional Department of social protection of the population is covered. The types of administrative and legal means of activity of the regional Department of social protection of the population are provided. Some administrative and legal means of activity of the Department of social protection of the population of Kharkiv regional state administration are characterized. It has been found out that administrative and legal means of activity of the regional Department of social protection of the population are methods of practical realization of its goals, tasks and functions. Such methods are a systematic set of steps that must be taken to accomplish the tasks of the regional Department of Social Welfare.

Key words: social protection of the population, administrative remedies, social assistance, Department of social protection of the population. 